\section{Influence of Manganese on Growth of Jack Pine and Black Spruce Seedlings}

\author{
by 1. K. Morrison and K. A. Armson
}

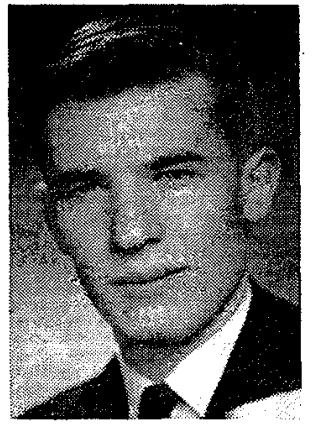

I. K. Morrison

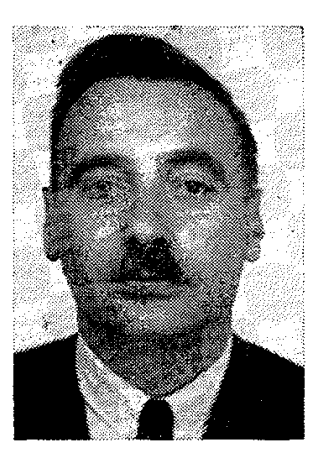

K. A. Armson

\section{Résumé}

Nos analyses d'aiguilles de pin gris et d'épinette noire, prises dans des peuplements naturels, corroborent les résultats d'observations antérieures: les aiguilles de l'épinette noire contiennent plus de manganèse que celles du pin gris; la teneure en fer est moindre chez l'épinette noire que chez le pin gris.

En chambre contrôlée, on a cultivé des semis d'épinettes et de pins avec des solutions de $M n$ titrées à 0, 0.1, 1, 10, et 100 p.p.m. C'est dans une solution contenant 0.1 p.p.m. de $M n$, que les deux espèces obtinrent leur meilleur développement. On na pas observé de différence de tolérance avec l'augmentation de $\mathrm{Mn}$ dans les solutions employées.

Aucune différence prononcée, dans la teneure en manganèse des aiguilles, ne fut observée, lors de ces études, au niveau des espèces, comme c'est le cas dans les peuplements naturels. Nous discutons des causes probables de ces faits.

\footnotetext{
Abstract

Analyses of foliage from natural stands of jack pine and black spruce confirmed earlier observations that levels of $M n$ were much higher in foliage of black spruce than in that of jack pine. Levels of $F e$ in jack pine foliage were greater than in black spruce.

In a grouth chamber experiment with spruce and pine seedlings and $M n$ supplied at 0, 0.1, 1, 10 and $100 \mathrm{ppm}$, both species grew best at the 0.1 ppm level and there was no evidence of difference in tolerance to high $M n$ levels. In this experiment, no marked species difference in foliar Mn concentrations was observed like that existing in natural stands. Possible reasons for this lack of difference are discussed.
}

Graduate Student and Professor, respectively, Foculty of Forestry, University of Toronto. Project supported by a grant from the Ontario

Foundation

Oxf. 181.34

\section{Introduction}

In a study on $\mathrm{Mn}$ and $\mathrm{Fe}$ in eastern Canadian conifers, Gamelin (1937) found that foliage of black spruce (Picea mariana (Mill.) BSP) contained higher concentrations of $\mathrm{Mn}$ than that of other species, including jack pine (Pinus banksiana Lamb.). He noted, too, an association of black spruce with $\mathrm{Mn}$-rich sites and jack pine with sites poorer in this element. Numerous investigators have linked high concentrations of soil Mn with injury to a number of plants, while others have noted species differences in absorption and tolerance. Berger and Gerloff (1947) associated a stem streak necrosis of potato (Solanum tuberosum L.) and Adams and Wear (1957) crinkleleaf of cotton (Gossypium herbaceum L.) with excess soil Mn, Ross (1961) suggested that some stem cankers in red oak (Quercus rubra L.) were related to high soil $\mathrm{Mn}$ concentrations. In France, Duchaufour and Rousseau (1960) demonstrated in culture the toxic effect of high concentrations of $\mathrm{Mn}$ on silver fir (Abies alba Mill.) seedlings. Ingestad (1958) provided data for Norway spruce (Picea abies (L.) Karst.) indicating that toxicity symptoms might not be expected until foliar manganese concentration was in excess of 374 parts per million. Below $20 \mathrm{ppm} \mathrm{Mn}$ was likely to be deficient.

It has long been observed that following fires in the boreal forest of eastern Canada, some upland sites have regenerated to black spruce, other apparently similar sites have regenerated to jack pine, and yet other sites have varying mixtures of both species. While many factors, including seed supply, seed bed and microclimatic conditions, doubtiess have influenced species composition, there exists the possibility that if difference in the tolerance of these two species to $\mathrm{Mn}$ exists, and if $\mathrm{Mn}$ levels in natural soils cover the appropriate ranges, then forest succession in terms of these two species may be affected. 


\section{Materials and Methods}

In late August 1963, foliage and raw humus ( $F$ \& H) samples were taken from 14 stands containing jack pine and black spruce, varying in height from 25 to 55 feet. These stands were located in the Chibougamau area $\left(49^{\circ} \mathrm{N}, 73^{\circ} 30^{\prime} \mathrm{W}\right)$ of Quebec on podsol and podsol-gley soils developed on glacial outwash sands and tills. For large trees, composite samples of current foliage representing the entire crown were taken. For smaller trees, composite samples were taken of current foliage from the mid to lower portion of the crown. These samples were taken to determine generally if the observations of Gamelin (1937), concerning the differences in manganese concentrations in jack pine and black spruce were valid. Manganese in plant and soil samples was determined by the periodate oxidation method (Metson, 1956). The orthophenanthroline method (Jackson, 1958) was used to determine Fe. Exchangeable cations in soils were determined following leaching with neutral normal ammonium acetate solution. Soil $\mathrm{pH}$ was determined electrometrically using 1:1 soil water mix.

Two experiments were carried out. The first of these was a preliminary study, in which $\mathrm{Mn}$ supply levels were varied from 0.5 to 500 ppm, with levels of other elements held constant. Almost complete mortality amongst seedlings at the highest $\mathrm{Mn}$ level after 62 days indicated the desirability of a downward shift in the working range of $\mathrm{Mn}$ concentration. A spectrographic analysis on surviving seedlings for $\mathrm{P}, \mathrm{K}, \mathrm{Ca}, \mathrm{Mg}, \mathrm{Na}, \mathrm{B}, \mathrm{Fe}$ and $\mathrm{Mn}$ showed for increasing $\mathrm{Mn}$ supply slight increases in the concentrations of the first six of these elements in both tops and roots, a marked increase in $\mathrm{Mn}$ concentration in the roots of both species but a decrease in $\mathrm{Fe}$ concentration. Because of the incompleteness of these data (due to mortality) they are not presented here, but this experiment led to a second in which greater control was exercised and in which the apparent $\mathrm{Mn}-\mathrm{Fe}$ interaction was further investigated.

In the second culture experiment, seeds of jack pine (Seed Zone 2, Ontario Department of Lands and Forests) and black spruce (Seed Zone 3) were pregerminated on moist filter paper, then placed in $10 \mathrm{oz}$. plastic tumblers filled with perlite, 10 seedlings per tumbler. These tumblers, which had three holes in the bottom, were inserted into light proof plastic trays into which appropriate nutrient solutions (Table 1) were pumped for a three-to fourhour period each day. Five levels of $\mathrm{Mn}$ were used: $0,0.1,1,10$ and $100 \mathrm{ppm}$. Mn was supplied as Mn$\mathrm{Cl}_{2} .2 \mathrm{H}_{2} \mathrm{O}$. Solutions, circulated in four-litre volumes, were changed weekly and the $\mathrm{pH}$ adjusted initially to $\mathrm{pH} 4.5$. The $\mathrm{Cl}$ concentration ranged from 286 ppm at 0 ppm $\mathrm{Mn}$ to $417 \mathrm{ppm}$ at $100 \mathrm{ppm} \mathrm{Mn}$, although over the range 0 to $10 \mathrm{ppm} \mathrm{Mn}$ the change in $\mathrm{Cl}$ concentration was less than $15 \mathrm{ppm}$. Thus, the effect of $\mathrm{Cl}$ may reasonably be discounted. As a measure of the osmotic pressure the total molar concentrations ranged from 0.012 gram moles per litre at $0 \mathrm{ppm} \mathrm{Mn}$ to 0.014 gram moles per litre at $100 \mathrm{ppm} \mathrm{Mn}$, with the change over the range 0 to 10 ppm $\mathrm{Mn}$ being negligible. Thus, the osmotic effect may be discounted also. The experiment was carried out in a growth chamber where the photoperiod was 16 hours; day temperatures were $21 \pm 1{ }^{\circ} \mathrm{C}$ and night temperatures $11 \pm 1^{\circ} \mathrm{C}$. Each treatment was replicated four times. The total growing period was 106 days and total seedling dry weight, top weight, root weight and $\mathrm{Mn}$ and $\mathrm{Fe}$ concentrations were determined at harvest.

To test if seed germination itself was affected by Mn levels, a small experiment was carried out in which jack pine and black spruce seeds were germinated in contact with solutions in which the $\mathrm{Mn}$ concentrations varied from 0 to $1000 \mathrm{ppm}$. No differences were found related to either $\mathrm{Mn}$ levels or species.

\section{Results and Discussion}

In natural stands the level of Mn was four to five times as great in black spruce foliage as in that of jack pine (Table 2). There were higher concentrations of $\mathrm{Mn}$ in raw humus from under black spruce than in raw humus from under jack pine. Levels of $\mathrm{Fe}$ in jack pine foliage were generally greater than in black spruce. No jack pine were present in the black spruce stands but, with one exception, black spruce were present in the jack pine stands. These results substantiate the findings of Gamelin (1937).

In the main experiment, both species attained maximum weight under the $0.1 \mathrm{ppm} \mathrm{Mn}$ treatment (Table 3 ). Statistically $(P=0.05)$, only seedlings of both species at $100 \mathrm{ppm}$ and jack pine at $0 \mathrm{ppm}$ were smaller than those at the $0.1 \mathrm{ppm}$ level. Seedlings of both species at the $100 \mathrm{ppm}$ level had slightly chlorotic foliage. There was no evidence of root necrosis as reported by Duchaufour and Rousseau (1959) for silver fir. Manganese concentration increased markedly in the tops of both species with increase in Mn supply. In roots there was little difference in $\mathrm{Mn}$ at the 0 and 0.1 concentrations, but a marked increase at 1,10 and $100 \mathrm{ppm}$. Concentrations of $\mathrm{Mn}$ in roots of black spruce at these levels of supply were approximately twice that in jack pine roots. Fe levels in the tops of both species were similar and varied little with Mn supply: Fe concentrations in roots were greatest at the lowest level of Mn supply and were much greater in jack pine than in black spruce.

Table 1.

Consumption of nutrient solution supplied to seedlings.

\begin{tabular}{|c|c|c|}
\hline Source & $\begin{array}{l}\text { Element } \\
\text { Supplied }\end{array}$ & Concentration \\
\hline & & ppm \\
\hline $\mathrm{NH}_{4} \mathrm{NO}_{3}$ & Nitrogen & 112 \\
\hline \multirow[t]{2}{*}{$\mathrm{KH}_{2} \mathrm{PO}_{4}$} & Potassium & 78 \\
\hline & Phosphorus & 62 \\
\hline $\mathrm{CaCl}_{2} .2 \mathrm{H}_{2} \mathrm{O}$ & Calcium & 161 \\
\hline \multirow[t]{2}{*}{$\mathrm{MgSO}_{4} .7 \mathrm{H}_{2} \mathrm{O}$} & Magnesium & 48 \\
\hline & Sulphur & 64 \\
\hline $\mathrm{FeC}_{6} \mathrm{H}_{5} \mathrm{O}_{7} .7 \mathrm{H}_{2} \mathrm{O}$ & Iron & 2.84 \\
\hline $\mathrm{H}_{3} \mathrm{BO}_{4}$ & Boron & 0.42 \\
\hline $\mathrm{ZnSO}_{4} .7 \mathrm{H}_{2} \mathrm{O}$ & Zinc & 0.05 \\
\hline $\mathrm{MoO}_{3}$ & Molybdenum & 0.03 \\
\hline $\mathrm{CuSO}_{4} .5 \mathrm{H}_{2} \mathrm{O}$ & Copper & 0.02 \\
\hline \multirow[t]{2}{*}{ 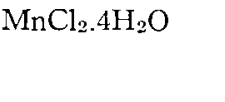 } & Manganese & $0.0 .1,1,10,100$ \\
\hline & Chlorine & $\begin{array}{r}286,286,287,287 \\
299,417 .\end{array}$ \\
\hline
\end{tabular}


The differences in foliage $\mathrm{Mn}$ levels in natural stands may well reflect not a species difference per se but rather the fact that black spruce has a much shallower root system than jack pine. As a consequence, a greater proportion of the absorbing roots of the spruce are in the upper organic layers of the soil wherein occurs the highest concentration and the most rapid turnover of $\mathrm{Mn}$. In the experiment, no such variation in root distribution occurred and similar levels of $\mathrm{Mn}$ in the tops of both species might be expected and were, in fact, found. Thus, it can be seen that while $\mathrm{Mn}$ toxicity as a phenomenon can be clearly demonstrated, it does not seem that species differences in $\mathrm{Mn}$ tolerance, at least at the seedling stage of development, occur. Both species showed maximum dry weight development at $0.1 \mathrm{ppm} \mathrm{Mn}$ and at increasing levels dry weight was reduced.

The nature of the inhibitory action of excess $\mathrm{Mn}$ on plant growth has been the subject of much investigation. Often too, excess $\mathrm{Mn}$ has been associated with symptoms similar to those of Fe de- ficiency. The toxicity of $\mathrm{Mn}$ may be related to one or more of the following three general mechanisms.

1. Excess $\mathrm{Mn}$ in the tissues is metabolically toxic to one or more of the vital processes.

2. Excess $\mathrm{Mn}$ may inactivate or substitute for $\mathrm{Fe}$, possibly precipitating the Fe or the organic reactant with which it was to combine. Somers and Shive (1942) proposed that if $\mathrm{Fe}$ is absorbed in the ferric state it is reduced to the ferrous state within the plant, but that excess Mn will cause its re-oxidation to the ferric state and subsequent precipitation as ferric-phosphorus organic complexes. Sideris and Young (1949) working with pineapple (Ananas comosus (L.) Merr.) concluded that the toxic effect of $\mathrm{Mn}$ resulted from its substitution for $\mathrm{Fe}$ in a precurser of chlorophyll. Hewitt (1954) advanced a similar view.

3. Excess $\mathrm{Mn}$ prevents entry of Fe into the plant or the transport of $\mathrm{Fe}$, if absorbed, from the roots to other parts of the plant. Twyman (1951) considered the absorbing process to be the limiting one in which $\mathrm{Mn}$ competes with Fe for absorp-

Table 2.

Manganese and iron concentrations and $\mathrm{pH}$ values for various natural stands of jack pine and black spruce in Quebec.

\begin{tabular}{|c|c|c|c|c|c|c|c|}
\hline \multirow{3}{*}{ Stand Type } & \multicolumn{3}{|c|}{ raw humus } & \multicolumn{4}{|c|}{ foliage } \\
\hline & \multirow{2}{*}{$\mathrm{pH}$} & \multicolumn{2}{|c|}{ exchange } & \multicolumn{2}{|c|}{ jack pine } & \multicolumn{2}{|c|}{ spruc } \\
\hline & & $\mathrm{Mn}$ & $\mathrm{Fe}$ & $\mathrm{Mn}$ & $\mathrm{Fe}$ & $\mathrm{Mn}$ & $\mathrm{Fe}$ \\
\hline & & \multicolumn{2}{|c|}{$\mathrm{ppm}$} & \multicolumn{2}{|c|}{$\mathrm{ppm}$} & \multicolumn{2}{|c|}{$\mathrm{ppm}$} \\
\hline Jack pine, young. & 3.6 & 30 & 5 & 150 & 73 & 770 & 40 \\
\hline Jack pine, young $\ldots \ldots \ldots \ldots \ldots \ldots$ & 4.1 & 60 & 3 & 100 & 137 & - & $\longrightarrow$ \\
\hline Jack pine, mature ................. & 3.7 & 70 & 8 & 170 & 179 & 690 & 35 \\
\hline Jack pine, mature $\ldots \ldots \ldots \ldots \ldots \ldots \ldots$ & 3.9 & 130 & 23 & 180 & 166 & 640 & 72 \\
\hline Jack pine, mature $\ldots \ldots \ldots \ldots \ldots \ldots$ & 4.1 & 60 & 3 & 170 & 232 & 750 & 104 \\
\hline Jack pine, mature $\ldots \ldots \ldots \ldots \ldots \ldots$ & 4.0 & 60 & 11 & 220 & 262 & 870 & 63 \\
\hline Black spruce, young . . . . . . . . . . . . & 4.0 & 220 & 35 & - & - & 630 & 118 \\
\hline Black spruce, young. . . . . . . . . . . . & 4.0 & 230. & 25 & - & - & 690 & 96 \\
\hline Black spruce, mature. . . . . . . . . . . . & 3.4 & 130 & 18 & - & -- & 660 & 72 \\
\hline Black spruce, mature. . . . . . . . . . . . . & 3.4 & 40 & 5 & - & - & 610 & 83 \\
\hline Black spruce, mature . . . . . . . . . . . . . & 3.8 & 110 & 10 & - & $一$ & 760 & 86 \\
\hline Black spruce, mature . . . . . . . . . . . & 4.0 & 200 & 11 & - & $-\ldots$ & 600 & 125 \\
\hline Burned cutover. & 3.9 & 100 & 5 & 100 & 221 & 170 & 52 \\
\hline$\ldots \ldots \ldots \ldots \ldots$ & 4.5 & 160 & 11 & 120 & 141 & 870 & 124 \\
\hline
\end{tabular}

Table 3

Seedling dry weights and manganese and iron concentrations.

\begin{tabular}{|c|c|c|c|c|c|c|c|c|}
\hline \multirow{2}{*}{ Species } & \multirow{2}{*}{$\begin{array}{l}\text { Mn } \\
\text { Supply } \\
\text { ppm }\end{array}$} & \multicolumn{2}{|c|}{ Dry weight } & \multicolumn{3}{|c|}{ Manganese } & \multicolumn{2}{|c|}{ Iron } \\
\hline & & top & root & total & top & root & top & root \\
\hline & & \multicolumn{3}{|c|}{ grams } & \multicolumn{2}{|c|}{$\mathrm{ppm}$} & \multicolumn{2}{|c|}{ ppm } \\
\hline \multirow{5}{*}{ Jack pine. } & 0 & 362 & 100 & 462 & 10 & 32 & 53 & 287 \\
\hline & 0.1 & 545 & 155 & 700 & 33 & 24 & 51 & 164 \\
\hline & 1 & 451 & 128 & 579 & 202 & 47 & 49 & 203 \\
\hline & 10 & 458 & 138 & 596 & 855 & 380 & 52 & 164 \\
\hline & 100 & 322 & 96 & 418 & 4445 & 1731 & 64 & 164 \\
\hline \multirow[t]{5}{*}{ Black spruce. . } & 0 & 219 & 26 & 245 & 27 & 35 & 60 & 90 \\
\hline & 0.1 & 273 & 36 & 309 & 45 & 33 & 68 & 82 \\
\hline & 1 & 236 & 28 & 264 & 167 & 85 & 56 & 51 \\
\hline & 10 & 261 & 34 & 295 & 1028 & 674 & 56 & 70 \\
\hline & 100 & 171 & 25 & 196 & 4256 & 3473 & 62 & 63 \\
\hline
\end{tabular}


tion sites or primary acceptors involved in the absorption of these ions. Smith and Specht (1953) working with seedlings of citrus trees observed that $\mathrm{Mn}$ did induce an $\mathrm{Fe}$ deficiency chlorosis and concluded that it did this by interfering with the upward transport of $\mathrm{Fe}$ since $\mathrm{Fe}$ accumulated in the roots.

In the present study, no attempt was made to as certain the mechanism of toxicity. Although the amount of $\mathrm{Mn}$ within the seedlings increased greatly with increase in external $\mathrm{Mn}$ and the Fe concentra-

\section{Literature Cited}

ADAMS, F. and WEAR, J. I. 1957. Manganese toxicity and soil acidity in relation to crinkle leaf of cotton. Soil Sci. Soc. Amer. Proc. 21: 305-309.

BERGER, K. C. and GERLOFF, G. C. 1947. Manganese toxicity of potatoes in relation to strong soil acidity. Soil Sci. Soc. Amer. Proc. 12: 310314.

DUCHAUFOUR, P. and ROUSSEAU, L. Z. 1959. Les phénomènes d'intoxication des plantules de résineux par le manganese dans les humus forestiers. Rev. For. Franc. 11: 835-847.

GAMELIN, H. 1937. Manganese and iron in the Pinales of Quebec. Ecole H.E.C. Montreal. Contrib. No. 8.

HEWITT, E. J. 1954. Metal interrelationships in plant nutrition. 2. The relation of metal toxicity, molybdenum and nitrogen source to chlorophyll and magnesium content of beet in sand culture. J. Expt. Botany 5: 110-118.

INGESTAD, T. 1958. Studies on manganese deficiency in a forest stand. Medd. Skogsforskn. Inst. 48: 4. tion decreased, the magnitude of the $\mathrm{Fe}$ decrease did not seem sufficient to explain the entire growth reduction in terms of a simple prevention of $\mathrm{Fe} a b-$ sorption alone. There is no indication that increased $\mathrm{Mn}$ supply has resulted in a reduced transport of $\mathrm{Fe}$ from the roots to the tops. Excess $M n$ may have prevented chlorophyll production to a degree or in some way inactivated the absorbed Fe; thus, seedlings at the $100 \mathrm{ppm} \mathrm{Mn} \mathrm{supply} \mathrm{were} \mathrm{slightly} \mathrm{chlo-}$ rotic. There remains the possibility that the toxicity effect of excess $\mathrm{Mn}$ on growth may be quite independent of $\mathrm{Fe}$ metabolism.

JACKSON, M. L. 1958. Soil chemical analysis. Prentice-Hall, Inc., Englewood Cliffs, N.J. pp. 389-390.

METSON, A. J. 1956. Methods of chemical analysis for soil survey samples. New Zealand Soil Bureau Bull. 12. pp. 115-116.

ROSS, E. W. 1961. The possible relation of manganese to stem cankers in red oak. Phytopathology 51: $579-581$.

SIDERIS, C. P. and YOUNG, H. Y. 1949. Growth and chemical composition of Ananas comosus (L.) Merr. in solution cultures with different iron-manganese ratios. Plant Physiol. 24: 416-440.

SMITH, P. F. and SPECHT, A. W. 1953. Heavy metal nutrition and iron chlorosis of citrus seedlings. Plant Physiol. 28: 372-382.

SOMERS, I. I. and SHIVE, J. W. 1942. The iron-man ganese relation in plant metabolism. Plant Physiol. 17: 582-602.

TWYMAN, E. S. 1951. The iron and manganese requirements of plants. New Phytol. 50: 210-226.

From Nova Scotia's Historic shores and storied green hills, the Department of Lands and Forests extends best wishes to the Canadian Institute of Forestry on the occasion of its Diamond Jubilee.

The sharpened use of Canada's forest resources makes the 1968 theme "New Forests for Old" — especially topical at St. John's, in September.

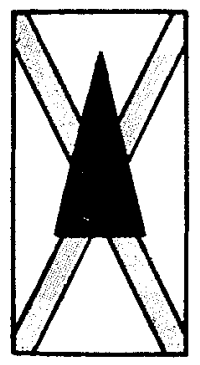

\section{Nova Scotia Department of Lands \& Forests}

STEPHEN T. PYKE Minister

\author{
G. W. I. CREIGHTON \\ Deputy Minister
}

